\title{
FOSTERING COMPETITIVE CITIES AND URBAN AREAS IN THE GREATER MEKONG SUBREGION: BUILDING INCLUSIVE ECONOMIC CLUSTERS SUSTAINABLY
}

Michael Lindfield

NO. 14

August 2017
ADB SOUTHEAST ASIA WORKING PAPER SERIES 


\section{ADB Southeast Asia Working Paper Series}

\section{Fostering Competitive Cities and Urban Areas in the Greater Mekong Subregion: Building Inclusive Economic Clusters Sustainably}

Michael Lindfield

No. 14 | August 2017
Michael Lindfield is an economist/financial analyst with over 30 years' experience in international sustainable urban development policy formulation and in designing the institutional and financial mechanisms to implement urban development and infrastructure policy and programs. He is currently engaged by a number of international agencies, providing advice on urban issues focusing on urban finance and urban climate-related investments. He is secretary of the Council of the Sustainable Infrastructure Foundation and chair of the Board of Asia Pacific Aid Partnerships. Until 2013, he was chair of the Urban Community of Practice at $A D B$ and the program manager for the Cities Development Initiative for Asia, an infrastructure project development facility which he founded. He has also managed urban policy institutions in the Netherlands and Australia. He has a Bachelor's degree in Architecture from Sydney University and a Master's degree in Commerce from the University of New South Wales in Australia. He obtained his PhD in Economics from Erasmus University in the Netherlands on the topic of Infrastructure Project Risk Assessment.

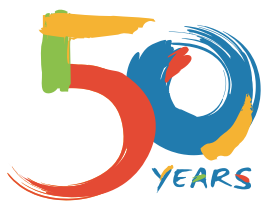




\section{Creative Commons Attribution 3.0 IGO license (CC BY 3.0 IGO)}

(C) 2017 Asian Development Bank

6 ADB Avenue, Mandaluyong City, 1550 Metro Manila, Philippines

Tel +632632 4444; Fax +6326362444

www.adb.org; openaccess.adb.org

Some rights reserved. Published in 2017.

Printed in the Philippines.

Publication Stock No. WPS178934-2

DOI: http://dx.doi.org/10.22617/WPS178934-2

The views expressed in this publication are those of the authors and do not necessarily reflect the views and policies of the Asian Development Bank (ADB) or its Board of Governors or the governments they represent.

ADB does not guarantee the accuracy of the data included in this publication and accepts no responsibility for any consequence of their use. The mention of specific companies or products of manufacturers does not imply that they are endorsed or recommended by ADB in preference to others of a similar nature that are not mentioned.

By making any designation of or reference to a particular territory or geographic area, or by using the term "country" in this document, $\mathrm{ADB}$ does not intend to make any judgments as to the legal or other status of any territory or area.

This work is available under the Creative Commons Attribution 3.0 IGO license (CC BY 3.0 IGO) https://creativecommons.org/licenses/by/3.0/igo/. By using the content of this publication, you agree to be bound by the terms of this license. For attribution, translations, adaptations, and permissions, please read the provisions and terms of use at https://www.adb.org/terms-use\#openaccess

This CC license does not apply to non-ADB copyright materials in this publication. If the material is attributed to another source, please contact the copyright owner or publisher of that source for permission to reproduce it. ADB cannot be held liable for any claims that arise as a result of your use of the material.

Please contact pubsmarketing@adb.org if you have questions or comments with respect to content, or if you wish to obtain copyright permission for your intended use that does not fall within these terms, or for permission to use the ADB logo.

Notes: In this publication, "\$” refers to US dollars.

Corrigenda to ADB publications may be found at http://www.adb.org/publications/corrigenda 


\section{CONTENTS}

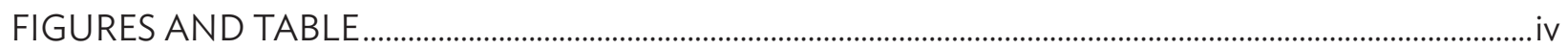

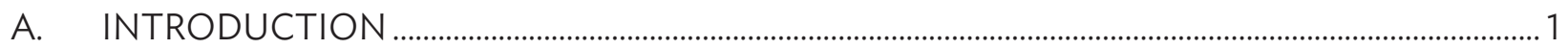

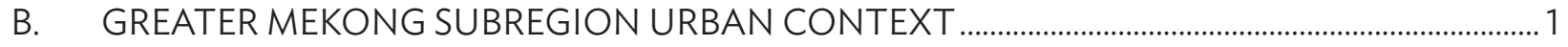

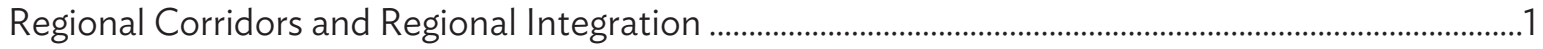

Greater Mekong Subregion Urban Development Strategic Framework:

Competitive Cities from the Beginning ...............................................................................................

Competitiveness Assessments in the Greater Mekong Subregion ............................................................. 5

C. INTERNATIONAL BEST PRACTICE IN FOSTERING COMPETITIVE CITIES .................................. 6

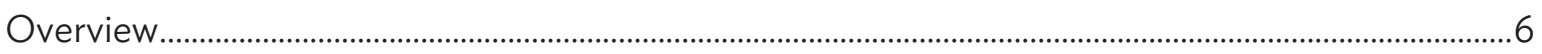

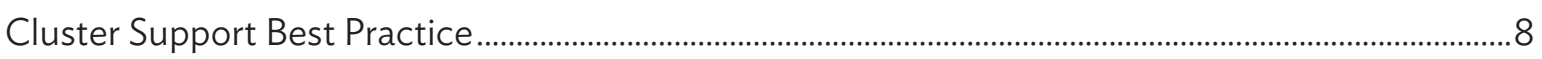

Competitive Cities Best Practice-An Enabling Framework

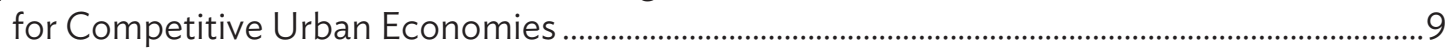

Best Practice in Cross-Border Coordination and Implementation Institutions ...................................11

D. WHAT SHOULD BEST PRACTICE APPLIED TO GREATER MEKONG SUBREGION

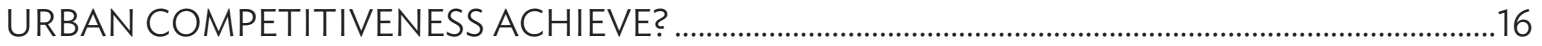

Status of Urban Systems in the Greater Mekong Subregion ........................................................................16

What Corridor Institutions Need to Achieve .................................................................................................... 17

E. IMPLEMENTATION ISSUES RELATED TO

COMPETITIVE URBAN ECONOMIES IN CORRIDORS........................................................................21

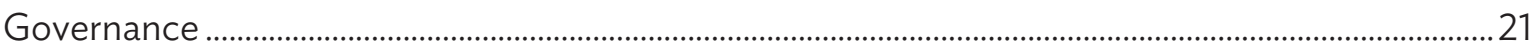

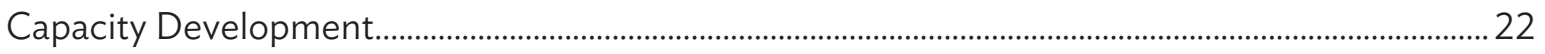

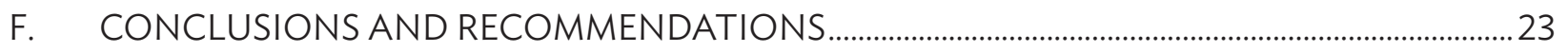

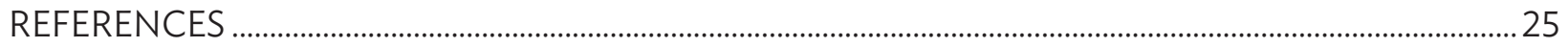




\section{FIGURES AND TABLE}

\section{FIGURES}

1 Sectoral Distribution of Greater Mekong Subregion Investment Projects

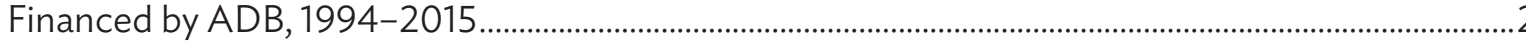

2 Greater Mekong Subregion Urban Development Strategic Framework ................................................4

3 Greater Mekong Subregion Southern Economic Corridor Force Field Analysis .....................................5

4 Greater Mekong Subregion Corridor Implementation Key Components ................................................

5 Corridor Implementation Institutional Hierarchy .......................................................................................

6 InterAmerican Development Bank Cluster Support Implementation Agencies ...................................9

$7 \quad$ Cluster Support Project Analysis and Development ...................................................................................10

8 TRAC Concession Project Financing Structure .......................................................................................13

9 Participants in N4 Concession Financing .................................................................................................... 13

10 Initiative for the Integration of Regional Infrastructure in South America

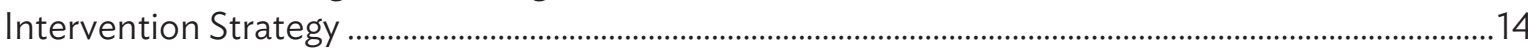

11 InterAmerican Development Bank-Financed Program for Industry Cluster Development and Competitiveness in the Province of Mendoza, Argentina (2005).......................15

12 Map of Greater Mekong Subregion Corridors ...................................................................................................19

\section{TABLE}

1 Supranational/National Collaboration 


\section{A. INTRODUCTION}

1. This discussion paper focuses on the urban aspects of Greater Mekong Subregion (GMS) corridor development and the institutional framework that will be needed to implement investments that will bolster the competitiveness of the region. Much work has been done on urban development in the GMS. The GMS Urban Strategy document ${ }^{1}$ clearly sets out three areas of focus and describes the cross-cutting theme of competitiveness. The GMS Task Force on Urban Development (TFUD) has previously discussed issues related to urban competitiveness in relation to a number of issues. ${ }^{2}$ In fact, the issue was raised at the first meeting of the TFUD in July 2013. Given the experience on a range of projects in the intervening years, it is timely to consider potential strategies, and institutional and funding models, which could further enhance the competitiveness of the region. The paper seeks to canvass such strategies and models.

\section{B. GREATER MEKONG SUBREGION URBAN CONTEXT}

\section{Regional Corridors and Regional Integration}

2. The emergence of development corridors, supported by dedicated institutional and funding structures, linking major cities across national boundaries is a relatively recent phenomenon. Fast-emerging markets and rapidly urbanizing cities now characterize the world's new economic geography (NEG). The NEG has changed the spatial scales and interconnectivity of cities across countries not only in the GMS and across Central Asia Regional Economic Corridor (CAREC), and within countries as in the Delhi-Mumbai Industrial Corridor (DMIC) and in the Pearl River Delta and Yangtze Multimodal corridors in the People's Republic of China. The physical manifestation of these trade corridors is seen in the associated "ribbon development," as between Bangkok and Ho Chi Minh City. These examples of trade/transport corridors all include a transport 'backbone' consisting of railways and/or roads (exceptionally, in the Philippines, with the "Nautical Superhighway" it is shipping routes), and major airports and/or seaports.

3. The economic benefit of transport corridors has been clearly demonstrated. ADB studies ${ }^{3}$ and those by others ${ }^{4}$ have found that economic benefits have accrued to new investors, the existing residents along corridors and to surrounding communities. The effects of development appear to be disbursing along corridors from major nodes - with small scale enterprises opening, for example along Road 9 in the Lao People's Democratic Republic (Lao PDR). Corridors have promoted the crowding in of foreign direct investment and some free trade zones for example the Trang Bang industrial area in Viet Nam and in and around Poipet and Mae Sot areas of Cambodia. Agricultural incomes within the area of influence of the corridor investments have also risen. Forty-six percent of households in the influence area of the Champasak Road Improvement Project increased their agricultural output. But "quick cash" businesses such as casinos can bring social disbenefits. Road safety and health issues can also be a challenge. Thus, in respect of the inclusiveness of corridors, performance has been mixed, with studies citing the need for

\footnotetext{
ADB. 2016. Greater Mekong Subregion Urban Development Strategic Framework. 2015-2022. Manila.

2 For example, ADB. 2014. Summary Proceedings of the Third Meeting of the GMS Task Force on Urban Development 11-12 September 2014, Vientiane Capital, Lao People's Democratic Republic. Manila, which summarizes the extensive discussions on the role of economic zones in bolstering regional economies.

3 For example, ADB. 2006. Infrastructure for Asian Interconnectivity. Manila.

4 See for example, Mulenga, G. 2001. Developing Economic Corridors in Africa: Rationale for the Participation of the African Development Bank. NEPAD, Regional Integration and Trade Department. No. 1. April 2013.
} 
better distributional analysis, along the lines of that conducted for the CAREC corridors, needed at the outset of corridor planning. Even in respect of enterprise development, an ADB study ${ }^{5}$ suggests that more support is needed for local enterprises to take full advantage of the opportunities offered by corridor development.

4. Corridor logic focuses first on spatial integration with effective transport and communication infrastructure which confers location advantages, mainly reduced transport, collaboration and other transaction costs, to add value to supply chains. The NEG concept highlights the crucial role of increasing returns to scale for agglomeration within corridors with firms being able to capture increased trade and investment opportunities, especially when trade barriers are removed. ${ }^{6}$ This new paradigm is made manifest spatially in economic corridors-as opposed to transport corridors-which are now promoted strongly both within and among countries. Such corridors potentially provide new opportunities for micro, small, or medium-sized producers, helping them overcome an inherent disadvantage stemming from their lack of economies of scale as suggested by the ADB study.

5. ADB has been a strong supporter of corridor development. In the GMS, as of December 2015, ADB had extended loans totaling $\$ 6.6$ billion for 76 investment projects costing about $\$ 17.8$ billion in total. These have involved subregional roads, railway improvements, hydropower projects, corridor town development, tourism infrastructure development, communicable disease control, trade facilitation and biodiversity conservation. GMS governments and development partners provided $\$ 4.7$ billion and $\$ 6.5$ billion, respectively, for these projects (Figure 1). In general, the core of these investments were road and rail transport links, which are the backbone of any corridor, although ADB has implemented some significant urban projects in the GMS corridors as well (see Figure 1).

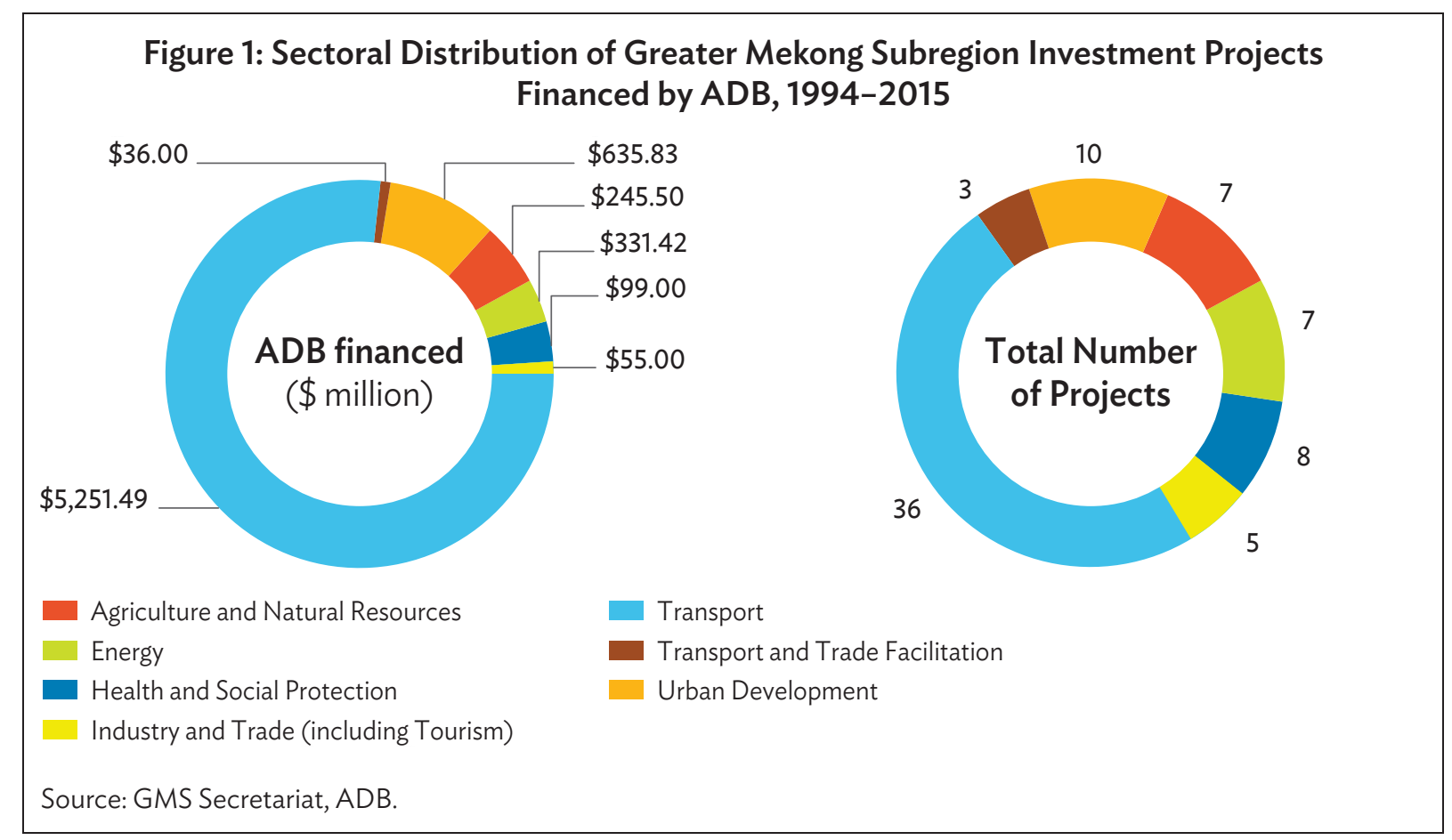

ADB. 2013. Economic Corridor Development for Inclusive Regional Integration. ADB. Manila.

6 A. Ascani et al. 2012.New Economic Geography and Economic Integration: A Review. SEARCH Working Paper. WP1/02 http://www.ub.edu/searchproject/wp-content/uploads/2012/02/WP-1.2.pdf 
6. However, despite progress in establishing good road and energy networks and improved urban infrastructure along corridors, many challenges remain in respect of the urban areas and their hinterlands located along these corridors, which have not been able to fully tap the potential benefits offered by this type of strategy. Further, corridor development has been criticized as adversely affecting certain groups, particularly the very poor and marginalized such as ethnic minorities and for having an adverse effect on the environment. ${ }^{7}$ In addition, some secondary cities along economic/transport corridors are suddenly experiencing rapid growth (often unplanned) and its related adverse social and environmental impacts. Finally, given that most corridors run, at least partially, within areas that are either environmentally sensitive and/or are subject to climate-related risks, the twin issues of climate positive development and resilience become much more important.

7. At the same time, increasing interconnectedness, both within and between economies is putting a strain on sectoral agencies and local governments, which have to cope with the dual roles of implementing national policy and developing and managing local economies. Reflecting the concerns addressed above, to these stresses are added calls for better performance on social, economic and environmental issues in the context of broader regional integration. In order to move forward, transport and logistics investments need to be more effectively integrated into (a) the economic base and (b) the spatial structure of urban nodes and their hinterlands; and do so in a way which enhances the positive environmental impacts of investments. In short, GMS corridors need to become economic corridors and these corridors need to be "green". To meet this need, more innovative solutions to transport and logistics issues are needed-in particular, from the private sector.

\section{Greater Mekong Subregion Urban Development Strategic Framework: Competitive Cities from the Beginning}

8. Much work has been done on urban development in the GMS. Several successful development projects targeting investments along GMS corridors have been implemented. ${ }^{8}$ The GMS Urban Strategy document 9 clearly sets out three areas of focus-border towns, corridor towns, and capacity development) and describes the key cross-cutting theme of competitiveness (Figure 2). The GMS Urban Development Task Force has previously discussed issues related to urban competitiveness in relation to a number of issues.

9. The urban development projects contained in the GMS Regional Investment Framework Implementation Plan (RIF-IP) to date has thus focused mainly on providing basic infrastructure within the "corridor towns" pillar. With the improved infrastructure as an outcome of the Corridor Towns Development Projects, the project is expected to address the problems of inadequate provision of urban infrastructure in secondary towns, supporting the objective of the second pillar of the Strategic Framework and helping transform the GMS transport corridors into full-fledged economic corridors. ${ }^{10}$ Three such projects have been implemented thus far with a fourth in preparation. However, the capacity development for urban management and investment in local infrastructure, such as local roads and drainage, water supply, waste water and solid waste, while essential, are not sufficient to foster the development of value-added clusters as the remaining constraints are still a disincentive for most investors. To date, ADB investment projects have not explicitly addressed the institutional structures

Oxfam Australia. 2008. A Citizen's Guide to the Greater Mekong Region. Melbourne.

8 F. Steinberg and A. Plaza. The Greater Mekong Subregion Corridor Towns Development Projects. In ADB. 2016. Urban Development in the Greater Mekong Subregion. Manila.

9 See Footnote 1.

10 ADB. 2011. The Greater Mekong Subregion Economic Cooperation Program Strategic Framework, 2012-2022. Manila. 
required to support the implementation of the first pillar-the Border towns-although technical assistance has been programmed for 2016. These areas raise a number of more complex issues for project implementation. Approaching these areas requires consideration of broader institutional and economic development issues - that is more rigorous focus on improving the competitiveness of GMS corridor towns.

Figure 2: Greater Mekong Subregion Urban Development Strategic Framework

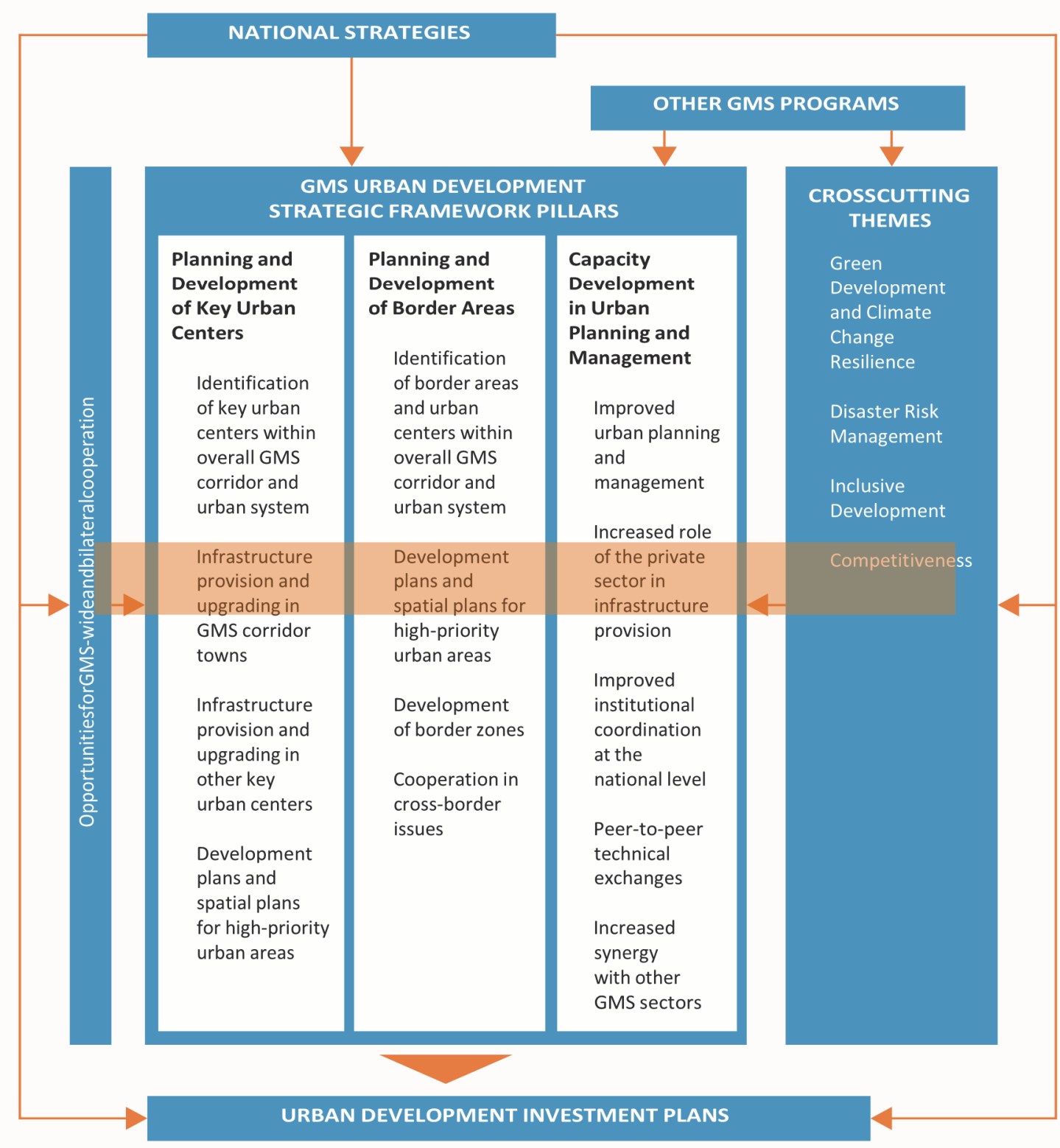

GMS = Greater Mekong Subregion.

Source: Asian Development Bank. 
The question, then, is: what form of institutional arrangements-for planning, project development, implementation and funding-will best foster competitiveness across the corridor as a whole? The paper reviews international best practice in this regard and assesses this practice in relation to the needs of the GMS region in the following sections.

\section{Competitiveness Assessments in the Greater Mekong Subregion}

10. The ADB GMS Corridor projects did examine the constraints to the development of townsusing a force-field analysis. An example of the Southern Economic Corridor analysis is set out in Figure 3. However, such a level of analysis is insufficient to target specific investments in support of industry clusters.

Figure 3: Greater Mekong Subregion Southern Economic Corridor Force Field Analysis
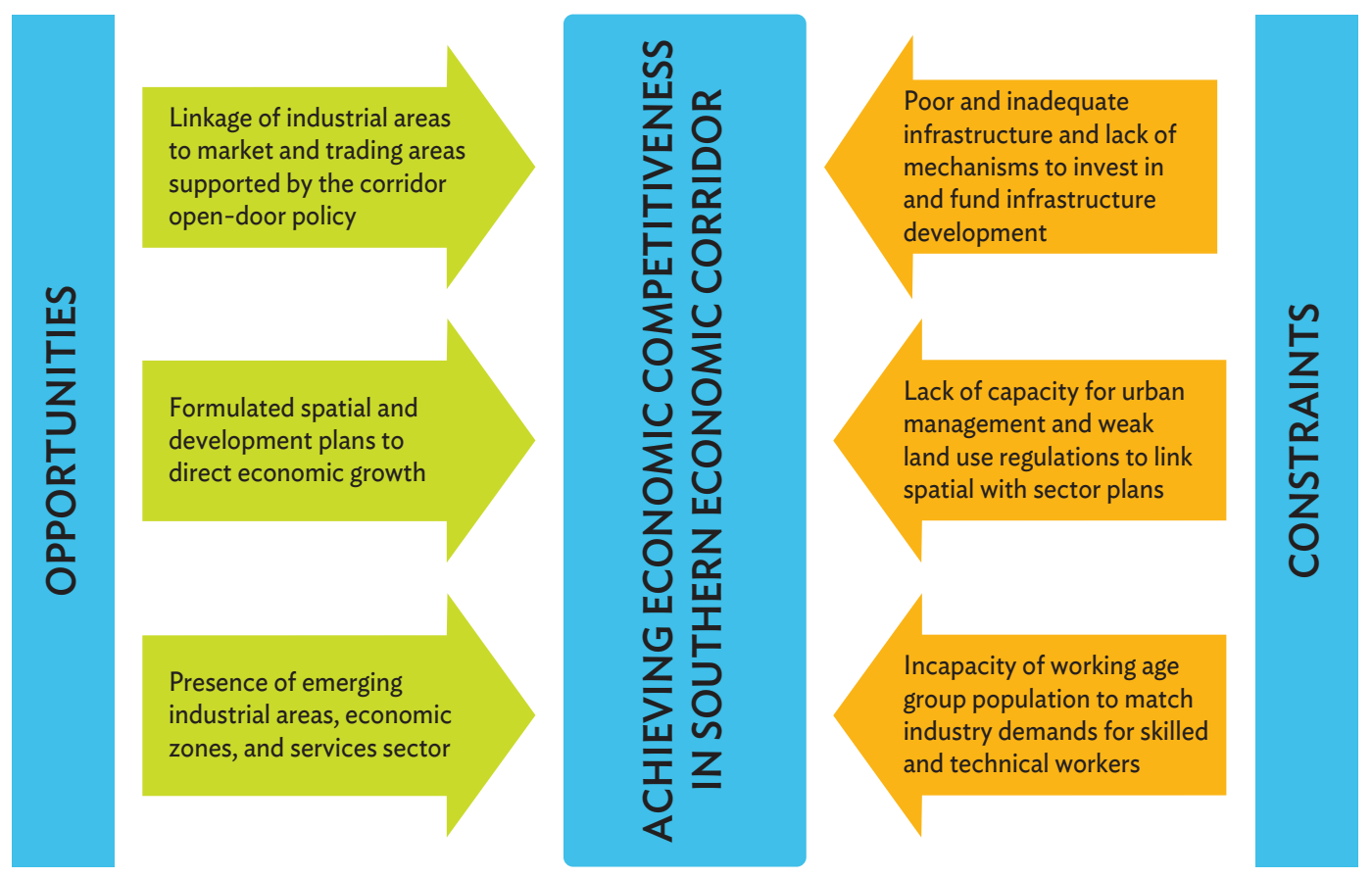

Source: Asian Development Bank.

11. With the exception of some preliminary work carried out by GIZ in the Siem Reap, ${ }^{11}$ no systematic work has been done to assess the physical infrastructure needed to support local industry clusters-particularly those which strengthen rural-urban linkages so vital to the inclusion of smaller cities into the economic development of the corridor. Assessments of the opportunities for increasing the value added to industry in Cambodia ${ }^{12}$ have focused on food processing and moving textile production "up market," and on diversification into mainly agro-based industry all of which require major investments in urban and intra-urban infrastructure. The Government of Cambodia has a focused

1 See GIZ Regional Economic Development Program. http://www.phnom-penh.diplo.de/contentblob/4526870/Daten/ 5446554/RED_Programme.pdf

12 See ADB. 2014. Cambodia: Diversifying Beyond Garments and Tourism. Manila. 
incentives system to promote such activity, but it is, as yet, poorly coordinated and not focused on the competitive advantage of the local area. The Government of Viet Nam has a similar policy based on government investment in industrial parks, again not informed by analysis of the infrastructure needs of local clusters. Thailand has a general incentive law and encourages the location in industrial estates, either public or privately developed, but again such estates, and the export processing zones within them are not designed in the context of the potential locally-based industry clusters. However, current institutions of corridor development do not enable these shortcomings to be effectively addressed.

12. In Cambodia particularly, but also applicable in Viet Nam, the World Bank also identified the absence of effective business financing for enterprises as a key constraint and, particularly in Cambodia, ${ }^{13}$ the transaction costs of un-transparent and inefficient governance. Public-private partnerships (PPPs) are difficult to structure in all three countries. Other key constraints, especially in Cambodia and Viet Nam, were the lack of skills development programs focused on the needs of potential clusters and the lack of technology development and dissemination.

\section{INTERNATIONAL BEST PRACTICE IN FOSTERING COMPETITIVE CITIES}

\section{Overview}

13. The concepts of city competitiveness (and the subsequent enabling framework needed to foster competitiveness) and (industrial) cluster development are distinct but separate and both apply to the development of GMS corridors. Corridor institutions need to be able to deliver both.

14. Cluster analysis of cities is an important tool focusing on the existing-and in some cases the potential-clusters of industries (service industries included) in a city. The analysis provides an evidence base for the development of polices to strengthen the performance of these clusters. The key question is: What are the key constraints to industrial clusters which have good potential to grow and supply jobs?

15. Competitive cities is a broader concept. The approach recognizes that it is important to foster competitive industries, and thus cluster development is a subset of this approach. But competitive cities address other areas as well. Examples of the elements considered important in this analysis can be seen in the Economist Hotspot Index, at the one end of the spectrum going into some depth on 39 main indicators. At the other end of the spectrum is the Philippines City Competitiveness index which has 3 main indicators.

16. International good practice in relation to corridors-discussed in detail below-shows that there are three key components of any implementation framework-infrastructure, cluster support, and finance (Figure 4). Such institutions need to work in the context of a holistic understanding of sustainability-fostering development that is not bolsters economic growth but is inclusive and environmentally sound and resilient.

13 P. Baily. 2008. Cambodian Small and Medium Sized: Enterprises: Constraints, Policies and Proposals for Their Development. In Lim, H. (ed.), SME in Asia and Globalization, ERIA Research Project Report 2007-5, pp. 1-36. 


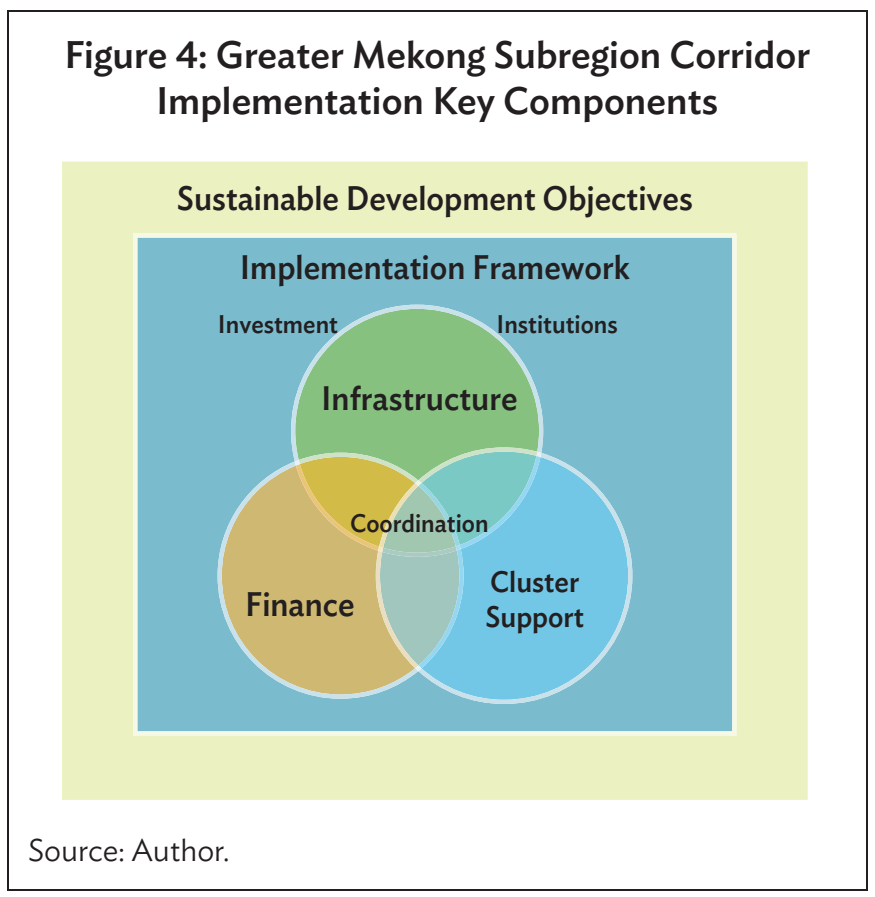

17. Such best practice occurs at three levels: at the level of the implementing agency, at the country level in terms of cross-agency coordination, and at the cross-national level. Figure 5 sets out the concept. In terms of infrastructure provision and financial institutions, current practice in the region is relatively developed, if not yet adapted to corridor development. However, institutions for cluster support and cross-national coordination are less developed and these two areas will be dealt with in some detail below, drawing on examples from other parts of the world.

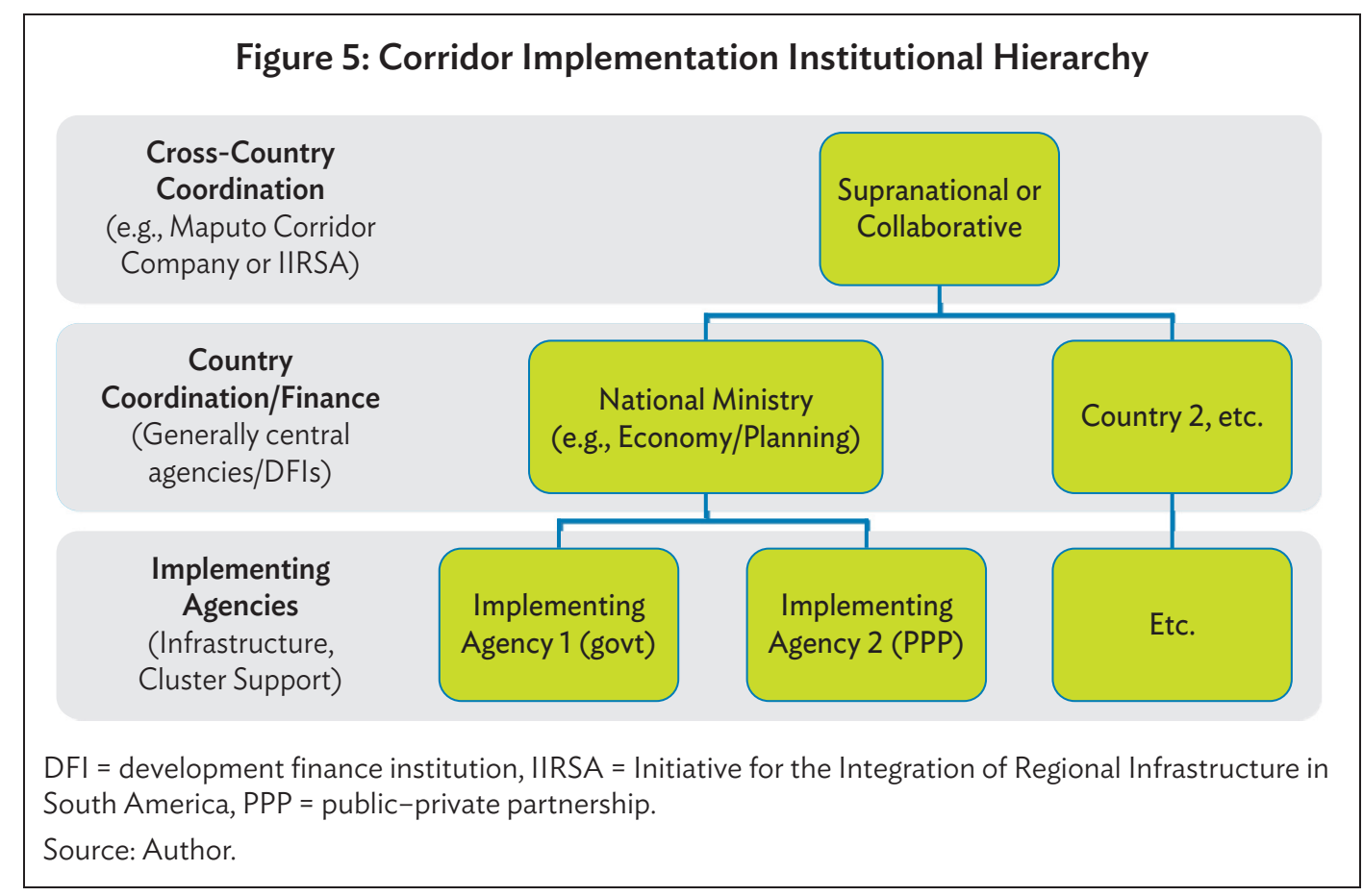




\section{Cluster Support Best Practice}

18. The InterAmerican Development Bank (IDB) has long been active in promoting industry clusters - the type of assistance is termed a Cluster Development Program (CDP). Such assistance ${ }^{14}$ is justified by the presence of coordination failures and positive externalities. Coordination failures impacting agglomeration economies ${ }^{15}$ are a widespread and well-known problem in development economics that may lead to a remarkably suboptimal allocation of resources if not properly addressed by policy interventions. As Rosenstein-Rodan ${ }^{16}$ points out, coordination failures emerge in the presence of externalities that make the investment decision of one agent interrelated to those of others. For example, an investment by one firm can have positive effects on the profitability of another firm to the point that, without the former, the latter would not be economically viable.

19. Solving coordination failures is one of the key objectives of CDPs. These interventions create formal and informal institutional frameworks to facilitate private-private, public-private, and public-public collaboration. To induce more collective action among private firms, programs often strengthen a local business association, help create a new association, or create a new "cluster association." Firms may choose to join a cluster association if the common interests of firms in a cluster do not coincide with existing sectorial-type business chambers.

20. The spread of CDPs has been fast and relatively recent despite starting a few years later than in Europe. Similar to Organisation for Economic Co-operation and Development countries, these interventions have been formed at the local, regional and national levels. International institutions such as the IDB, the Multilateral Investment Fund, the European Union, the United States Agency for International Development, and the United Nations Industrial Development Organization financed many of the early CDPs. The IDB has very actively financed such public programs in the Latin American and Caribbean region. The number of clusters supported since the early 2000 s by various organizations of the IDB group is impressive-180 clusters with 18 loans of $\$ 300$ million on average. ${ }^{17}$

21. The financing structure of an IDB-supported CDP varies according to the needs of the country and region. Usually, a local counterpart of the IDB provides a strong component of the financing for cluster activities, which are frequently delivered by the private participants. This combination of financing and delivering offers an important indirect advantage. It enhances the probability of a program's success since private agents, which are mostly small and do not have extensive financial resources, face clear opportunity costs-they need to see the benefits of co-investing with the government in a joint venture. Figure 6 sets out a typical program structure.

14 A. Maffioli, C. Pietrobelli, and R. Stucchi, eds. 2016. The impact evaluation of cluster development programs: methods and practices. Washington, DC: IDB.

15 Papers presenting evidence of agglomeration economies include P. Combes, G. Duranton, L. Gobillon, D. Puga, and S. Roux. 2012. The Productivity Advantages of Large Cities: Distinguishing Agglomeration from Firm Selection. Econometrica 80(6): 2543-2594.

16 P. N. Rosenstein-Rodan. 1943. Problems of Industrialization of Eastern and South-Eastern Europe. The Economic Journal 53(210/211): 202-11.

17 See Footnote 15. 


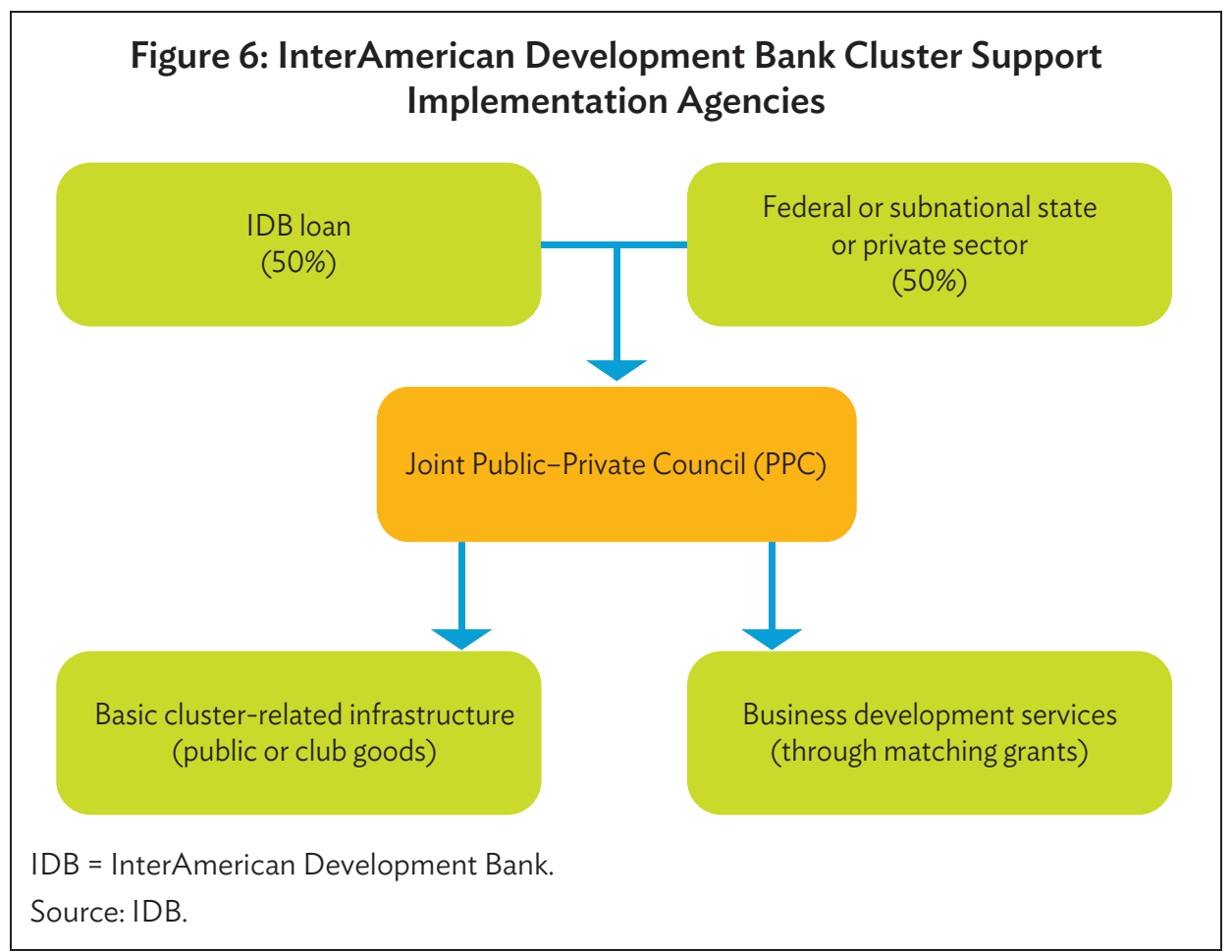

\section{Competitive Cities Best Practice-An Enabling Framework for Competitive Urban Economies}

22. Competitive cities analysis tends to use 'benchmarking' on a number of indicators. As discussed above the Economist Intelligence Unit's Hot Spots 2025: Benchmarking the future of competitiveness of cities (2013) ranks 120 cities on Institutional Effectiveness, Physical Capital, Social and Cultural Character, Human Capital, Financial Maturity, Global Appeal and Economic Strength using the 39 indicators. This level of ambition is perhaps somewhat more detailed than is necessary for GMS cities and urban areas, but the Philippines City Competitiveness Index which covers Economic Dynamism, Government Efficiency and Infrastructure is both very tailored to Philippine conditions (one of the 10 sub-indicators for infrastructure is "Number of Automated Teller Machines") and is not yet sufficiently reflective of the sustainability issues facing GMS urban areas.

23. In general, the indices benchmark against indicators of economic development, social development and the environment in the city. Cross-cutting all of these issues is 'governance'. But what is governance in reality? It is having the institutions in place and operating effectively in delivering the policy and planning, project development and financing needed to put in place the economic, social and environmental infrastructure and systems needed by the citizens of the city. 
24. ADB has developed an approach to assessing Competitive Cities and formulating approaches to supporting their priority clusters. ${ }^{18}$ The analysis is based on the research of Michael Porter ${ }^{19}$ and focuses on his key elements of an effective cluster-firm structure and rivalry, factor conditions (especially human capital), demand conditions, related and supporting industries, government support (infrastructure, etc.). The process is shown in Figure 7. ADB has developed methods for such analysis. The output of such analysis would be a cluster project along the lines of the IDB approach.

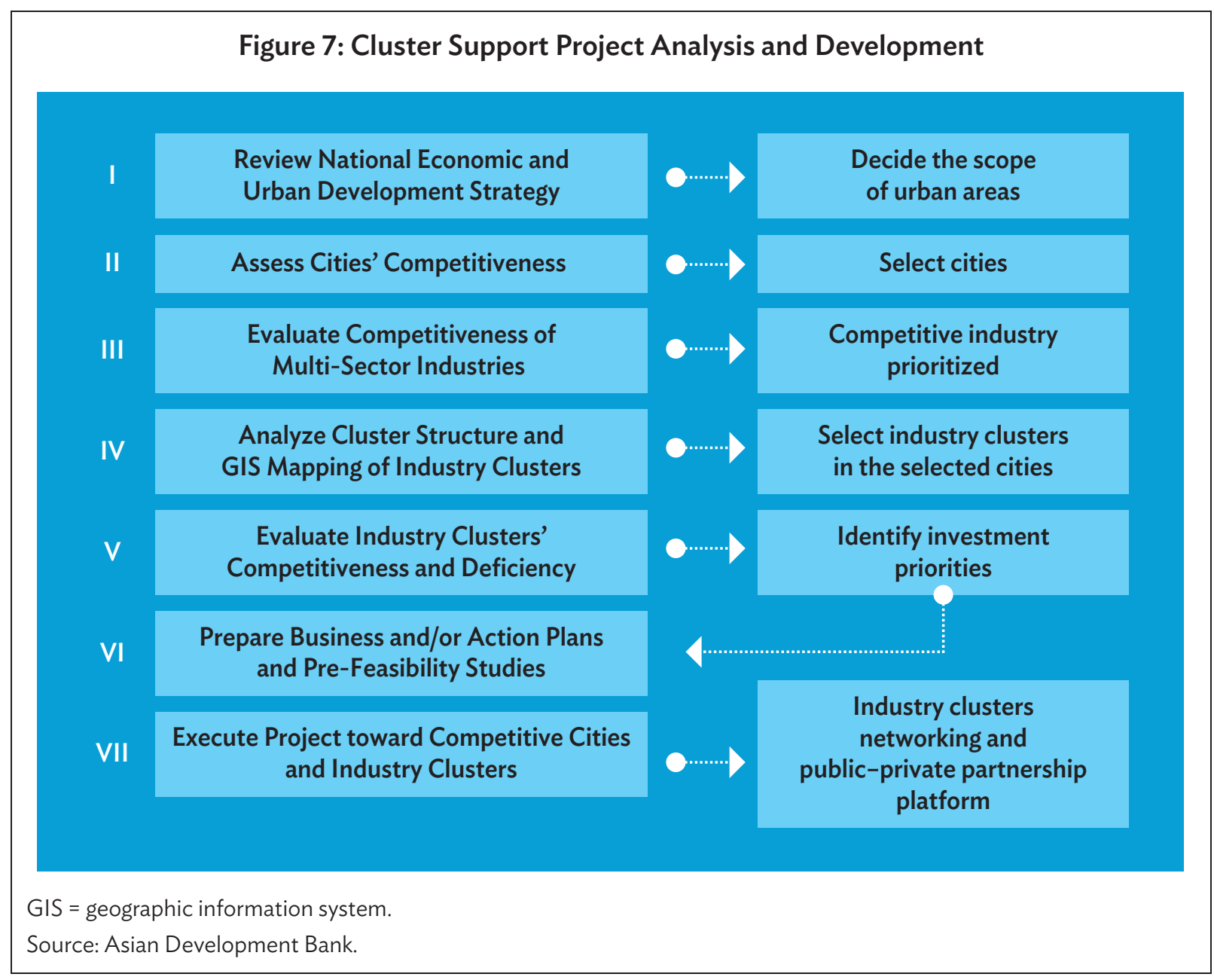

25. It should be noted that the IDB projects have two main components-infrastructure and business support. Such projects are unusual for ADB urban, but could be implemented through appropriate development corporations set up for particular urban areas or economic zones. As such they could be implemented in the GMS using established urban development mechanisms supported by a flexible financing mechanism - capable of funding both infrastructure and supporting activities. The Results-Based Lending modality has such flexibility.

18 See K. Choe and B. Roberts. 2011. Competitive Cities in the 21st Century. Manila: ADB.

19 M. Porter. 1998. Clusters and the New Competitive Agenda for Companies and Governments. In M. E. Porter, ed. On Competition. MA: Harvard Business School Press. 


\section{Best Practice in Cross-Border Coordination and Implementation Institutions}

26. In relation to implementation mechanisms for corridor development there are diverse models.

\section{Supranational Constructs The Case of the Maputo Corridor}

27. In the late 1990s, South Africa promoted the Spatial Development Initiatives (SDIs) ${ }^{20}$ which were designed to strengthen South Africa's links to surrounding countries and the foster development in a number of identified corridors. First planned in 1994, the Maputo Development Corridor is considered to be a success story among SDI projects. The objective was to coordinate the development of the corridor between Johannesburg and Maputo with the N4 expressway at its core. ${ }^{21}$ This corridor was typical of many development corridors in that it had, at its end points, two large metropolitan areas, each with their own internal development corridors. The corridor also encompassed intermediate urban areas for which it had a mandate to promote development. The fact that it crossed international borders adds to the institutional complexity, but does not change the core conceptual design issues. The key elements of the development corridor institutions, as initially designed, were: ${ }^{22}$

a. An effective intergovernmental (national/province) governance and funding structure.

Specifically:

(i) A significant dedicated budget funded by South Africa mainly through the Development Bank of Southern Africa (DBSA) and through facilitation of private sector investments - in particular project finance for the N4 and for the Maputo port-focused on promoting economic development. ${ }^{23}$

(ii) A coordination mechanism - the Maputo Corridor Company (MCC) - with the MCC board and the management team focused on delivering required performance as defined by the Board, which provided a focused and responsive planning context including coordination of planning, SME and infrastructure development initiatives in the corridor through formal mechanisms of liaison with international and national funding agencies. The MCC chaired an interministerial committee of agencies related to corridor development. The nonprofit company was headquartered in Maputo and was jointly owned by the governments of South Africa and Mozambique. It had provision for private sector entities and for the governments of Swaziland, Botswana, and Zimbabwe to join as shareholders. ${ }^{24}$

(iii) The Company had good relations with South African national agencies and the Mpumalanga Development Corporation, but its governance structure was not so inclusive of local communities. This, combined with powers to override local opposition, made it vulnerable to accusations of overriding the legitimate interests of local enterprises and residents.

20 See http://www.mcli.co.za/mcli-web/mdc/sdi.htm

21 See http://www.mcli.co.za/mcli-web/mdc/mdc.html

22 See F. Soderbaum. 2001. Institutional Aspects of the Maputo Development Corridor. Development Policy Research Unit, Capetown: University of Cape Town.

23 P. Viljoen. 2006. Regional Integration Through Infrastructure Development.

24 C. Jenkins, J. Leape, and L. Thomas. 2000. Gains from Trade in Southern Africa. London: Macmillen Press. 
12 | ADB Southeast Asia Working Paper Series No. 14

(iv) Use of PPP modalities for implementation was core, specifically in the N4 implementation, and in the development of the Maputo port (discussed above) and smelter-which had support from DBSA (for $\$ 101$ million), the Industrial Development Corporation of South Africa (for \$125 million-since exited, see below) and the World Bank (the IFC invested \$120 million in the project-since exited). ${ }^{25}$

b. Effective implementation structure comprising

(i) The nascent Corridor Company worked with the Mpumalanga Development Agency (now the Economic Growth Agency) ${ }^{26}$ to catalyze area-focused activities associated with the N4 and the opportunities for market access it offered particularly for tourism and agriculture, but this work, although modest, was hampered by a lack of resources on both sides. ${ }^{27}$

(ii) A mechanism to deal with social inclusion/relocation (for example, ensuring that the SPV for the N4 contracted local communities to maintain the road). Using existing agencies (or special purpose organization), which can fund local communities or enterprises, acquire, develop and sell land either itself or in conjunction with a provincial agency.

(iii) As the company engaged in PPP projects, it had the authority to bid such projects and to enter into special purpose vehicles and/or joint ventures, and the capacity (held by a combination of its staff, state agencies, and consultants) to formulate, structure, implement and manage such projects.

28. The MCC structure was conceived as a way to avoid the establishment of an international organization by treaty - a very long process even between willing partners and as a way of providing an "exit strategy" for the South African SDI institutions. This structure was not, however, in the end, able to gain consensus from key South African institutions (the coordination unit moved to the DBSA, which did not have the ability to catalyze investments) or sufficient to obtain "buy-in" from the Mozambique government. With the failure to fully establish the MCC, momentum was lost and the effective structure for implementation was diluted resulting in the development of the corridor slowing markedly. ${ }^{28}$ A private sector initiative the Maputo Corridor Logistics Initiative was designed to partly fill the institutional vacuum. This initiative subsequently included government stakeholders, but its structure as a nongovernment organization registered in South Africa limits its effectiveness. This being said, the corridor area did benefit significantly from the investments made under the MCC auspices, and some momentum has been subsequently lost due to less effective coordinating structures. ${ }^{29}$

29. The use of cross-border PPP as an implementation modality was an interesting feature of the Maputo Corridor development. The financing structure for the 30 year BOT concession for the N4 Tollway (operated by the TRAC-Trans African Concessions-group) and the consortium participants in the concession financing are shown in Figures 8 and 9.

5 Various announcements of involved institutions.

26 See for example: www.opportunityonline.co.za/articles/mega-opportunities-in-mpumalanga-1281.html

27 See for example: www.mpumalanga.gov.za/otp/newsroom/speeches/archived_speeches/1999_archived_speeches/ Speech10Aug99.htm

28 See I. Shutte. 2005. Maputo Development Corridor: Evaluation of First Phase CSIR. Pretoria.

29 S. Sequeira, O. Hartmann, and C. Kunaka. 2014. Reviving trade routes: evidence from the Maputo Corridor. Discussion papers, 14. SSATP, Washington, DC. 


\section{Figure 8: TRAC Concession Project Financing Structure}

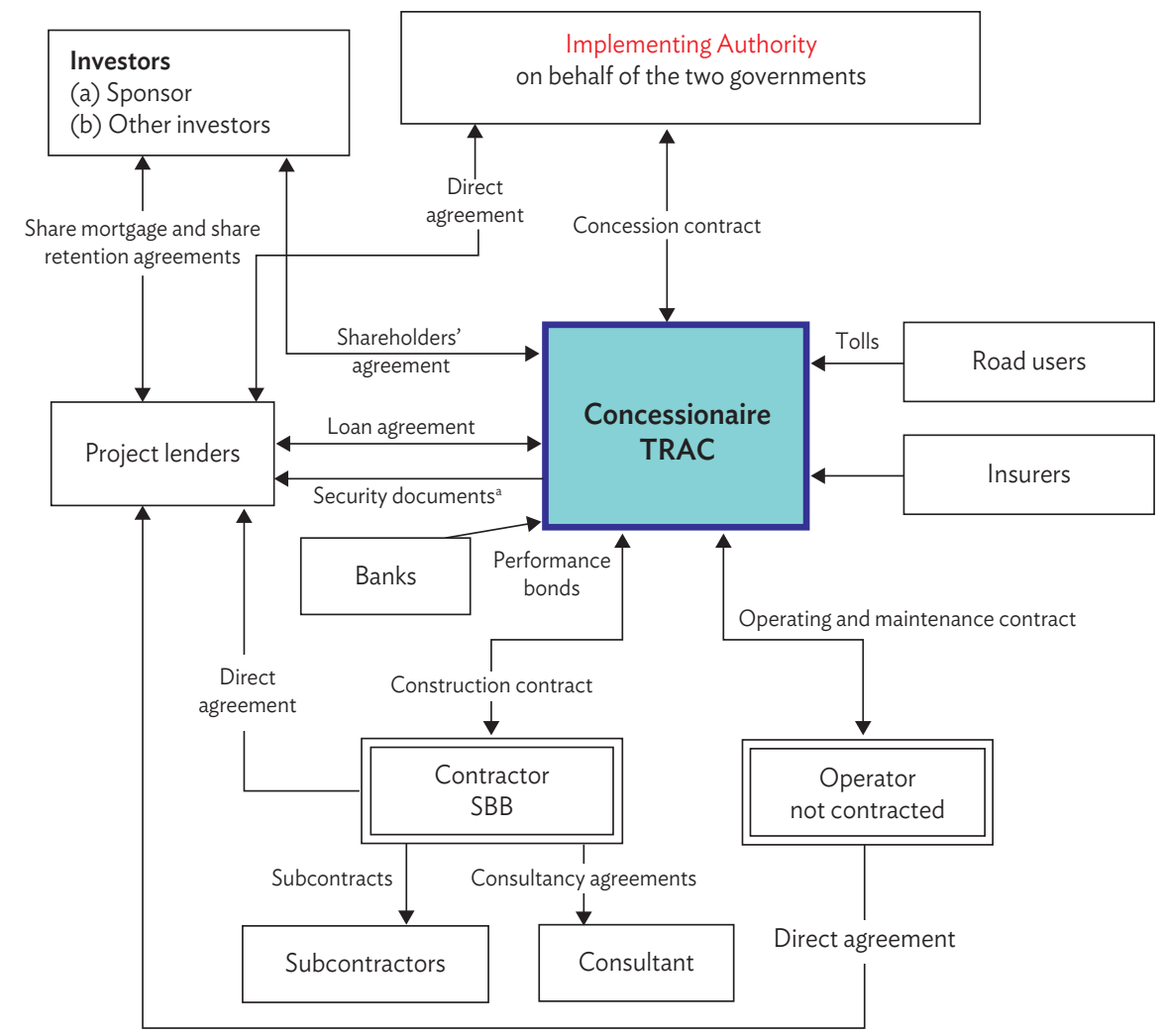

SBB = Stocks \& Stocks, Bouygues \& Basil; TRAC = Trans African Concessions.

Source: World Bank.

\section{Figure 9: Participants in N4 Concession Financing}

\begin{tabular}{l|l} 
Equity (Sponsors/construction companies) \\
Bouygues (Fr) \\
Basil Read (SA) \\
Stocks and Stocks (SA) \\
Equity (Non-sponsors) \\
South African Infrastructure Fund (SA) \\
Rand Merchant Bank Asset Management (SA) \\
Commonwealth Development Corporation (UK) \\
South African Mutual Life Assurance (SA) \\
Metropolitan Life Ltd (SA) \\
Sanlam Asset Management (SA) \\
SCDM (Moz) \\
Debt (excluding equity investors who also provided debt) \\
ABSA Corporate and Merchant Bank (SA) \\
Development Bank of Southern Africa (SA) \\
First National Bank (SA) \\
Mine Employees and Officials Pension Funds (SA) \\
Nedcor Bank (SA) \\
Standard Corporate and Merchant Bank (SA)
\end{tabular}

$\mathrm{Fr}=$ France; Moz = Mozambique; $\mathrm{SA}=$ South Africa; SBB = Stocks \& Stocks, Bouygues \& Basil; TRAC = Trans African Concessions; UK = United Kingdom.

Source: World Bank. 
32. IIRSA was created from a proposal to the Meeting of Presidents of South America in 2000 and its secretariat is funded by IDB, CAF (the Andean Fund), the Financial Fund for the Development of the Plate Basin, BENDES (the Brazilian Development Bank), and the World Bank. It coordinates the provision of infrastructure in the development corridors of Latin America, both traditional infrastructure and major cluster projects with infrastructure components. Such a cluster development project is the IDB's Program for Industry Cluster Development and Competitiveness in the Province of Mendoza, Argentina. This $\$ 105$ million loan has a major infrastructure component. The components are: (i) public infrastructure to support productive activities ( $\$ 75.56$ million); (ii) improved access to financial services (\$19.21 million); (iii) technical-vocational training (\$7.28 million); and (iv) a cluster promotion program pursuing cooperation among companies, associations, and institutions in the development and implementation of competitiveness improvement initiatives ( $\$ 4.02$ million). The structure of the project is shown in Figure 11.

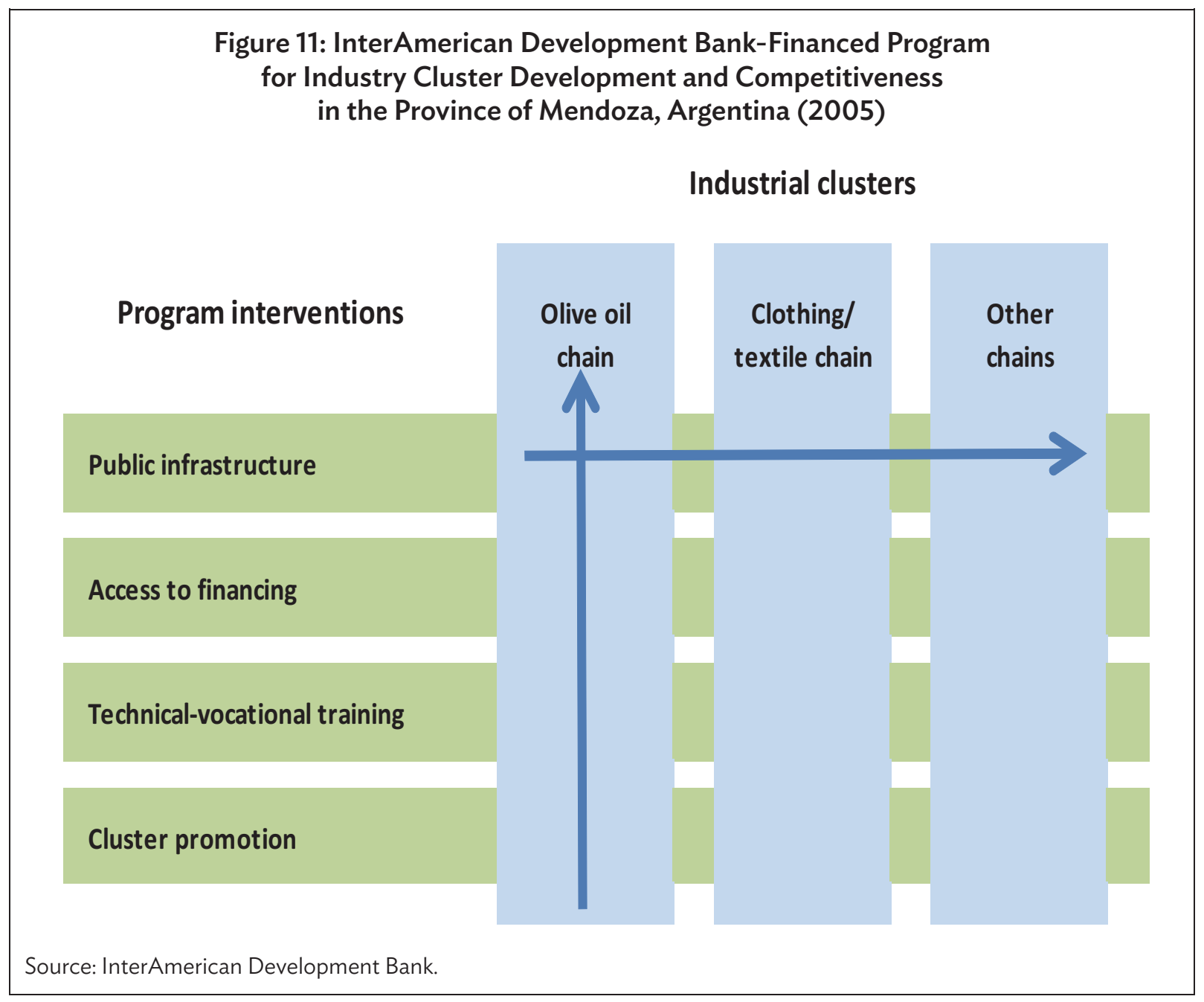


16 | ADB Southeast Asia Working Paper Series No. 14

\section{WHAT SHOULD BEST PRACTICE APPLIED TO GREATER MEKONG SUBREGION URBAN COMPETITIVENESS ACHIEVE?}

\section{Status of Urban Systems in the Greater Mekong Subregion}

33. Key indicators of GMS urbanization show some significant differences from global averages. ${ }^{30}$ With the world over 50\% urbanized, urbanization levels are clearly low in the GMS at 33.1\% for the region as a whole. Only Thailand approaches global norms with an official urbanization level of 44.1\% and a "real" level of somewhat over $50.0 \%$. Cambodia and Myanmar have strikingly low urbanization levels (19.5\% and 22.1\%, respectively), while Viet Nam's level of urbanization (29.6\%) is much lower than expected, given its level of economic development.

34. In all cases, GMS governments, with the exception of the People's Republic of China (PRC), have not encouraged accelerated productive urbanization. Until recently, most have discouraged urbanization, including Thailand and Viet Nam. The new administration of the PRC has indicated that it intends to further accelerate urbanization, especially in under-urbanized provinces such as Yunnan and Guangxi. The PRC is the only jurisdiction in the GMS with an overtly pro-urbanization policy stance. The other jurisdictions were negative, skeptical, or neutral to urbanization in the period before 1990. In contrast to its policies in the late 20th century, Viet Nam now encourages moderate urbanization.

35. However, urban growth rates in the region are high by world standards - particularly when related to relatively low national population growth rates in the region-especially in the PRC and Thailand. When taken as a ratio of national (provincial in the case of the PRC) population growth rates, urban populations are growing fastest in the PRC, especially Guangxi, and Thailand. These jurisdictions also exhibit the strongest economic performances, which is probably not a coincidence. Myanmar and Viet Nam have been experiencing the lowest urban growth rates in the GMS. However, as earlier discussed, it is expected that Viet Nam will be the third fastest-growing urban system in the GMS-essentially a latecomer to rapid urbanization. And it is likely that Myanmar's future urbanization rates will rise with economic development.

36. In the structure of the urban systems across the seven GMS jurisdictions, the share of urban population living in cities larger than 1 million varies from a high of 49.4\% in Guangxi, $47.5 \%$ in Cambodia, and $43.4 \%$ in Yunnan to a low of $28.5 \%$ in Thailand. Only the Lao PDR lacks a city over 1 million in size.

37. Generally speaking, the share of population living in cities from 250,000 to 1 million is low in the region. An exception is Guangxi, which has a well-balanced urban system. To the extent possible, national urbanization policies should support the development of a system of strong second tier (250,000-1 million) "workhorse" cities in the GMS. This would entail facilitating the graduation of some current cities in the 100,000-250,000 range with the potential to play a strategic role in the GMS to the 250,000-500,000 category.

30 J. Hakim. The Evolution of Towns and Cities in the Greater Mekong Subregion. In ADB. 2016. Urban Development in the Greater Mekong Subregion. Manila. 
38. Cambodia, Myanmar, and Viet Nam have considerable portions of their urban populations living in small cities from 50,000 to 250,000 in size (41.5\%, 42.1\%, and $26.3 \%$, respectively). The Lao PDR, Thailand, Yunnan, and, to a lesser degree, Viet Nam have strikingly large portions of their urban populations living in settlements less than 50,000 in size, which are mainly rural region service centers. In the Lao PDR, 44.9\% of the urban population live in such small settlements, while Thailand and Yunnan have more than $30 \%$ of their urban population living in small settlements.

39. The majority of the urban population in cities over 50,000 in the GMS are on the ADB-defined corridors. However, there is wide variance in the urban population's occupancy of the corridors. Cambodia and the Lao PDR already have $100 \%$ of their urban population in cities over 50,000 on the GMS corridors, Myanmar has 74\%, and Viet Nam has $69 \%$. Thailand, whose southern provinces are not part of the GMS, has 55\% of its population on the GMS corridors. In Yunnan, the figure is 47\%, and in Guangxi, it is only 34\%. This is because much of the territory of these jurisdictions is outside the GMS corridor system.

\section{What Corridor Institutions Need to Achieve}

40. Based on the foregoing analysis, strengthening the GMS urban system has a series of implications. ${ }^{31}$ Webster suggests focusing on the main corridors (see map) of which there are 6 main ones (with numerous subcorridors). Given that there has not been a systematic effort to gather and assess data for these corridors, seeking common themes, characteristics, and drivers affecting GMS cities, such analysis is needed for planning investment based on forecasted urban development opportunities and demand, with corridors serving as one instrument to facilitate development of the GMS urban system. Several areas should form the focus of corridor development.

\section{Multimodal Corridors}

41. The lack of rail transport connecting GMS cities puts the urban system at a major disadvantage relative to competing East Asian multinational regions. Fortunately, rail systems within GMS countries are being improved or have proposed improvements on a significant scale such as the double-tracking of the rail network in Thailand, proposed upgrading of the Yangon-Mandalay rail link, construction of a Kunming-Kyaukphyu rail link, upgrading of the Yunnan east-west rail corridor, expansion of high-speed railway service in the PRC to Nanning and Kunming, and possible construction of a Kunming-Bangkok high-speed railway link, among others. The challenge will be to interconnect these upgraded domestic rail routes. For GMS corridors to be green, they need to incorporate rail. However, assuming the continued high dependence of the GMS on highway transport, ADB and other institutions with a regional mandate could consider facilitating more energy, pollution, and greenhouse gas-efficient highway travel, especially for trucks. Investments in multimodal terminals and other logistics infrastructure are thus needed in GMS urban areas and appropriate financing mechanisms need to be developed. Measures to address these issues have been identified and a European Union-funded project focusing on Green Freight ${ }^{32}$ will support GMS governments in their implementation. But such initiatives need to be scaled up.

31 This section largely summaries D. Webster and A. Gulbrandson. The Role of Cities and Connectivity in Promoting Regional Integration and Competitiveness. In ADB. 2016. Urban Development in the Greater Mekong Subregion. Manila.

32 See: https://www.adb.org/news/green-freight-approach-needed-greater-mekong-subregion-workshop 


\section{Intermediate-Sized Cities}

42. In the GMS, the population living in cities of $250,000-1$ million is smaller than expected. National governments and international development agencies should encourage the development of medium-sized cities where a strong rationale exists. Such a rationale needs to be realistic-e.g., based on tourism and/or amenity, regional service functions, and agricultural processing-and locations should be ideal such as junctions, which feature high accessibility. What should be avoided at the national and international levels is an attempt to decentralize manufacturing, create too many tourist destinations (often without sufficient attraction), or encourage city building from a supply side approach ("build it and they will come") simply to generate more balanced rank-size systems within countries or along specific corridors. There is no need to ensure regular spacing of cities along corridors as long as service complexes exist at regular intervals. Where a case for investment exists, development of such key medium-sized cities along priority corridors should be encouraged.

43. Examples of these cities include the following: Bago, Mawlamyine, Khon Kaen, Louangphabang, Udon Thani, Phitsanulok, Mukdahan, Preah Sihanouk, Da Nang-Hue, Lang Son-Pingxiang, Dongxing and Ruili.

\section{Green Cities}

44. Much has been written about green cities, both internationally and specific to East Asia. It would be redundant to elaborate on what constitutes a green or sustainable city. In a nutshell, green cities have high, but variable densities (with nodes to encourage high ridership of public transit), contiguous physical development, and judicious allocation of green space (e.g., to areas with too many industrial zones or areas that have too much green space). They encourage development of energy-efficient buildings, are water-sensitive in their development, emphasize electric or alternative powered public transit, carefully regulate rural-urban land conversion on the urban edge, and financially incentivize less pollution and greenhouse gas emissions and waste at the household and firm levels. Because household incomes are relatively low in GMS cities-with the exception of Bangkok, and to a lesser extent Ho Chi Minh City, Kunming, and Nanning-consumption pressures are relatively subdued, but will grow fast.

45. On the supply side, the GMS system is challenged by an abundance of small cities, which makes it more difficult to achieve high environmental performance because they lack ridership for electric trains, have lower densities, and may lack capital for high environmental performance buildings, among others. Furthermore, many of these cities, especially the more remote ones, lack adequate knowledge of technologies and approaches to improve their environmental performance.

46. ADB has targeted smaller cities in the GMS, which will make urban greening initiatives more difficult to upscale in the GMS if action is limited to these cities. Small urban settlements offer much less potential for significant environmental sustainability improvements such as high-rise buildings, electric powered transport, and high density urbanization conserving surrounding farmlands. One exception is solar electricity, which loses efficiency from having collectors on vertical high-rise surfaces compared to rooftop installations on detached or row housing and low-rise buildings associated with smaller settlements. However, this advantage is diminishing. ${ }^{33}$

33 Sunrise. 2008. Barriers for the Introduction of Photovoltaics in the Building Sector. http:// www.pvsunrise.eu/pv-diffusionin-the-building-sector-bipv/studies-publications.html (accessed 10 March 2013). 
Figure 12: Map of Greater Mekong Subregion Corridors

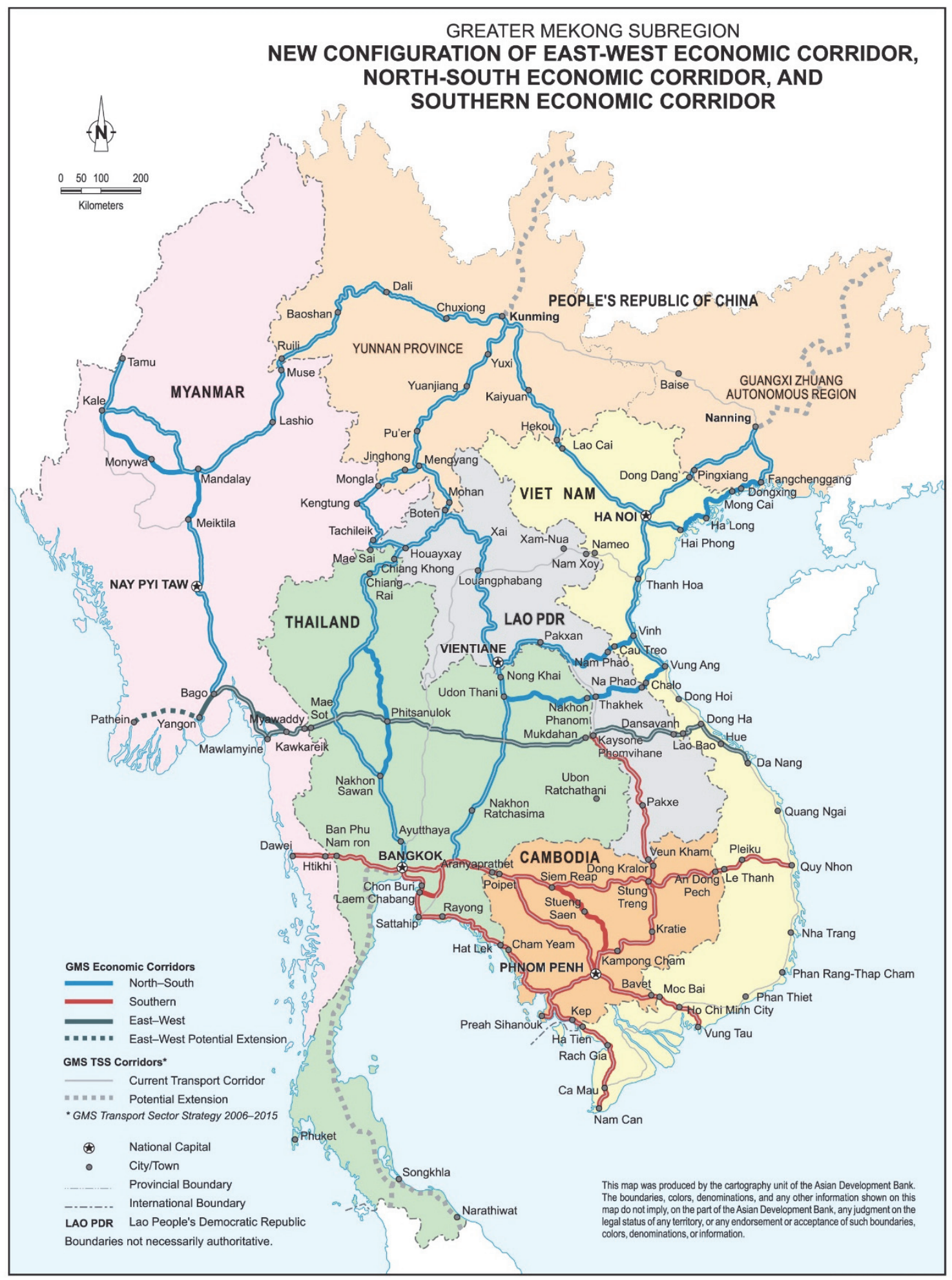

Source: Asian Development Bank. 


\section{Private Sector Involvement in the Greater Mekong Subregion Corridor Development}

47. The amount of capital and expertise needed to develop the urban system of the GMS, especially outside the PRC and Thailand, is enormous. Quality city building is mainly a function of the private sector, guided by public priorities and institutions. Thus, measures need to be taken to interest the private sector in investment opportunities in GMS cities, perhaps through a GMS urban investment fair.

48. The public sector-nationally and at the urban level-needs to establish mechanisms and priorities for public-private partnerships (PPPs). The PRC, including Guangxi and Yunnan, is currently prioritizing innovative financing such as PPP initiatives to encourage city building. This is due to the current PRC administration's wish to accelerate urbanization, especially in noncoastal regions with low levels of urbanization such as Guangxi and Yunnan.

\section{Agriculture and Logistics Considerations in Corridor Development}

49. One of the main potential benefits along corridors is increased value added in agriculture, both in crops (cropping systems and productivity) and agriprocessing. Realistically, most territory along corridors will never attract manufacturing or large numbers of tourists, with the exception of key tourist destination areas along corridors. Thus, agriculture-along with logistics and servicing support to vehicles, freight, and people moving along corridors - is the prime economic and livelihood opportunity. To this end, agricultural and environmental agencies need to be more involved in urban development along corridors. Development of quality service centers requires public sector leadership and private investment, or PPP initiatives. As argued, economic activity suited to corridors should be geographically clustered to the extent possible to create larger urban places. Too many small urban settlements are neither economically efficient nor environmentally desirable, including from a perspective of land efficiency.

\section{Tourism and Amenity as a Major Driver of Greater Mekong Subregion Development}

50. Tourism is a major element of the GMS economy-albeit still only about $5 \%$ of the region's gross regional product-and will grow much faster than the overall GMS economy. Tourism diversifies, as it has in Thailand, into second home communities, health services, amenity migration, and residences for knowledge workers. This will happen in the high amenity areas of the region such as the Yunnan Amenity Corridor and the prime beach area of Central Viet Nam. In Thailand, amenity dynamics have already dramatically reshaped the urban system. Amenity and tourism centers such as Phuket, where the urban population increased from 91,000 to 358,000 between 2000 and 2010, have eclipsed the former second-tier regional centers such as Hat Yai and Khon Kaen in importance. PRC authorities are increasingly preparing for this dynamic, especially in the case of Yunnan. However, more understanding and preparation for the dramatic impact of amenity drivers on cities and the urban system are needed in other countries of the GMS.

51. ADB has recognized the importance of tourism in the GMS, as has UNESCO, but there is a need to broaden the concept to specifically address the Meetings, Incentives, Conferences and Event (MICE) market, among others. There is a lack of recognition that amenity and tourism activity in the GMS is primarily urban based. The fact that a significant proportion of the GMS cities will have tourism and amenity-based economies has been overlooked in much of the urban analysis of the GMS region to date. Tourism planning for the region often wrongly assumes it to be a rural rather an urban activity. 


\section{E. IMPLEMENTATION ISSUES RELATED TO COMPETITIVE URBAN ECONOMIES IN CORRIDORS}

\section{Governance}

52. Governance effectiveness remains a crucial factor to progress on more broadly spreading the benefits of corridor developments and maximizing positive climate outcomes and inclusiveness. Better institutions are needed to build the green economic infrastructure of cities and towns and links to their rural hinterlands, connecting to national and international markets. As discussed above there are two main models - a supranational entity and a decentralized model based on collaboration of national entities. Table 1 below sets out some of the issues which need to be considered in choosing a structure.

Table 1: Supranational/National Collaboration

\begin{tabular}{|c|c|c|c|}
\hline \multicolumn{2}{|l|}{ Supranational e.g., MCC } & \multicolumn{2}{|c|}{ National Collaboration e.g., IIRSA } \\
\hline Advantages & Disadvantages & Advantages & Disadvantages \\
\hline & $\begin{array}{l}\text { Much harder to establish } \\
\text { initially }\end{array}$ & $\begin{array}{l}\text { Easier to establish initially- } \\
\text { uses country systems }\end{array}$ & \\
\hline \multirow{2}{*}{$\begin{array}{l}\text { "Authority"/mandate } \\
\text { established from the } \\
\text { beginning }\end{array}$} & & & $\begin{array}{l}\text { Continuous negotiation over } \\
\text { mandates relating to issues }\end{array}$ \\
\hline & $\begin{array}{l}\text { More structured-difficult } \\
\text { to negotiate change }\end{array}$ & More flexible & \\
\hline $\begin{array}{l}\text { Can do strategic planning } \\
\text { and implementation in } \\
\text { one entity-lower } \\
\text { coordination costs }\end{array}$ & & & $\begin{array}{l}\text { More difficult to link and } \\
\text { coordinate planning and } \\
\text { implementation-higher } \\
\text { coordination costs }\end{array}$ \\
\hline $\begin{array}{l}\text { Likely better capacity to } \\
\text { structure, and bargaining } \\
\text { power in relation to, } \\
\text { financing }\end{array}$ & & $\begin{array}{l}\text { Funding can be adapted to } \\
\text { country legal and economic } \\
\text { circumstances }\end{array}$ & \\
\hline \multirow[t]{2}{*}{$\begin{array}{l}\text { More focused capacity } \\
\text { building }\end{array}$} & & & $\begin{array}{l}\text { Need to have broader capacity } \\
\text { building effort }\end{array}$ \\
\hline & $\begin{array}{l}\text { Potentially less inclusive of } \\
\text { local communities } \\
\text { (more difficult) }\end{array}$ & $\begin{array}{l}\text { Potentially more inclusive } \\
\text { of local communities }\end{array}$ & \\
\hline $\begin{array}{l}\text { Potentially less subject } \\
\text { to political interference }\end{array}$ & $\begin{array}{l}\text { Potentially less responsive } \\
\text { to legitimate national/local } \\
\text { needs }\end{array}$ & & \\
\hline $\begin{array}{l}\text { Easier for one or more } \\
\text { governments to influence } \\
\text { decisions on corridor } \\
\text { development }\end{array}$ & $\begin{array}{l}\text { More difficult for country } \\
\text { vested interested to } \\
\text { influence development }\end{array}$ & $\begin{array}{l}\text { More difficult for one or } \\
\text { more governments to } \\
\text { influence decisions on } \\
\text { development directions }\end{array}$ & $\begin{array}{l}\text { Easier for vested interests to } \\
\text { have influence }\end{array}$ \\
\hline
\end{tabular}

IIRSA = Initiative for the Integration of Regional Infrastructure in South America, MCC = Maputo Corridor Company.

Source: Author. 


\section{Capacity Development}

53. Based on best practice experience, there is both an established methodology and institutional structure to operationalize this need. There is also, given the GMS structures and ADB experience thus far, a willingness and some capacity at both national and local levels, to strengthen coordination and capacities within sectoral agencies and subnational/local governments in order to facilitate large investments in infrastructure targeted to improve the inclusiveness and environmental sustainability of such economic/transport corridors.

54. However, it is difficult for subnational governments to respond. This is because economic and population growth has already placed heavy demand on overstretched local governments to extend already strained public services, particularly give their limited financial basis, weak partnership mechanisms and their lack of diagnostic tools to inform processes such as planning and budgeting. It is clear that more capacity support-the third pillar of the Strategic Framework-is needed to create the dynamic, responsive and adaptive institutions and systems required.

55. Thus, in addition to investments, a regional knowledge and best practice dissemination platform would be helpful to catalyze and support the corridor initiatives. Such a platform could foster the adoption of best practice and long term consistency in the approach to the development of the corridor by supporting the development of long term strategies "owned" by participating governments and by providing access to quality knowledge and best practice information. The platform could, given the major components of GMS urban strategy and proposed areas of focus set out above, promote three major streams of activity needed to promote green economic corridors. These are:

(i) Strengthening of diagnostics to identify priority urban investments fostering inclusive 34 and sustainable and resilient growth in economic corridors to support clusters within cities and rural areas-and addressing the capacity shortfalls constraining the implementation of such investments.

(ii) Strengthening the skills and systems of national funding agencies and implementing organizations to utilize such diagnostics, implying capacity assessment of, and capacity development programs for, improved: (a) planning/governance structures; (b) financing systems; and (c) partnership mechanisms among the community, governments, the international development assistance community and the private sector.

(iii) Catalytic resourcing of the preparation of required green urban and cluster development investments through appropriate funding channels, crowding in other development agency and climate funds, and the private sector.

34 In both the economic sense-providing infrastructure so lower income groups can better access resources and markets and in the social sense-in terms of fostering nonmotorized transport and improving road and occupational safety issues in transport investments. 
56. Private sector involvement and innovation will be particularly important in the implementation of such initiatives within corridors. In particular, such support can foster investment in the areas of urban design technology, ${ }^{35}$ infrastructure, ${ }^{36}$ and information technology. ${ }^{37}$ Private sector financial institutions can also be involved in the financing of such investments. In all these areas, there are opportunities for PPPs. It is possible to make a commercial return on many of these investments, it the projects are structured well. However, in many countries, the institutional structures that form the enabling framework for the investments are missing or lack the capacity to foster competitive private participation. In some instances, financing for such investments is not available from local financial institutions or capital markets. Further, the institutions and financing for government counterpart systems and facilities is often not available.

\section{F. CONCLUSIONS AND RECOMMENDATIONS}

57. International good practice relating to the effective implementation of agreed urban investment strategies in cross-border corridors such as the GMS indicates that a credible process is in place to: (i) analyze the economy of priority corridor cities; (ii) identify priority infrastructure investments to foster inclusive economic development and improve the environment; (iii) develop projects to implement needed investments; and (iv) match implementing agencies with appropriate funding institutions. Such processes need to be inclusive of local interests, ensuring that they would benefit from investments.

58. It has been found that such a process can be coordinated by either a supranational body or consensus-based coordination mechanism. Both arrangements are more effective if linked to a dedicated financing mechanism which provides for sustainable financing of investments in the long term. Supranational arrangements were used in the South African-fostered cross-border Spatial Development Initiative corridors in the late 1990s, the most effective of which was the Maputo Corridor catalyzed initially by the Maputo Corridor Company. These entities need to be strongly backed, both financially and institutionally -in the case of the Maputo Corridor Company by the South African Department of Trade and Industry and the Development Bank of Southern Africa. Consensus-based coordination mechanisms are illustrated by the Initiative for the Integration of Regional Infrastructure in South America Initiative (IIRSA) supported by IDB, which coordinates action across mandated national agencies structured according to their own laws and encompassing their own institutions.

59. Given that the appropriate decision on such structures will take some investigation, establishment of a consensus way forward, and investment in institutional structures, in the shorter term, the more immediate question is: What are the short-term urban investment priorities for GMS corridors?

60. Given the broader institutional issues, such shorter-term investment programs should also lay the basis for longer term collaboration and investment structures. It is suggested that, given the previous focus on the corridor towns described above, such programs could focus on the first pillar of the strategyborder towns-and bolster activities related to the third pillar-capacity building focused on developing viable corridor institutions.

35 For example, in energy efficiency of buildings, distributed energy generation.

36 For example, in economic zone infrastructure, multimodal terminals, feeder roads, dedicated freight routes, storage facilities, border crossings, decongesting city through ways, ports, and airports.

37 For example, e-governance, asset management systems, congestion pricing systems. 
61. A focus on border towns, and particularly in relation to the Border Economic Zones (BEZs), does however raise many of the issues related to the development of the whole corridor and should be addressed with a view to building institutions relevant to the whole corridor. The important issues in this regard are those relating to the country coordination mechanisms needed for the planning, financing, construction and operation of the BEZs. Such coordination can be done using established arrangements at the GMS level, but will require the GMS TFUD to support the process. A mechanism, possibly an ADB Regional Technical Assistance project, ${ }^{38}$ to establish and disseminate best practice and develop capacity in relevant fields also needs to be established. ADB can also assist through developing and catalyzing appropriate corridor financing mechanisms.

38 ADB. 2013. Technical Assistance to the Greater Mekong Subregion for Capacity Development for Economic Zones in Border Areas. Manila. 


\section{REFERENCES}

ADB. Green Freight in GMS. https://www.adb.org/news/green-freight-approach-needed-greatermekong-subregion-workshop (accessed 5 October 2016).

_. 2006. Infrastructure for Asian Interconnectivity. Manila.

2011. The Greater Mekong Subregion Economic Cooperation Program Strategic Framework, 2012-2022. Manila.

_. 2013. Economic Corridor Development for Inclusive Regional Integration. Manila.

_ 2013. Technical Assistance to the Greater Mekong Subregion for Capacity Development for Economic Zones in Border Areas. Manila.

_2014. Cambodia: Diversifying Beyond Garments and Tourism. Manila.

_. 2016. Greater Mekong Subregion Urban Development Strategic Framework 2015-2022. Manila.

Ascani, A. et al. 2012. New Economic Geography and Economic Integration: A Review. SEARCH Working Paper. WP1/02. http://www.ub.edu/searchproject/wpcontent/uploads/2012/02/WP-1.2.pdf (accessed 12 October 2016).

Baily, P. 2008. Cambodian Small and Medium Sized: Enterprises: Constraints, Policies and Proposals for Their Development. In Lim, H. ed. SME in Asia and Globalization, ERIA Research Project Report 2007-5, pp. 1-36.

Choe, K., and B. Roberts. 2011. Competitive Cities in the 21st Century. ADB: Manila.

Combes, P., G. Duranton, L. Gobillon, D. Puga, and S. Roux. 2012. The Productivity Advantages of Large Cities: Distinguishing Agglomeration from Firm Selection. Econometrica 80(6): 2543-2594.

European Union Sunrise Project. 2008. Barriers for the Introduction of Photovoltaics in the Building Sector. http://www.pvsunrise.eu/pv-diffusion-in-the-building-sector-bipv/studiespublications.html (accessed 10 September 2016).

GIZ. Regional Economic Development Program for the Greater Mekong Subregion. http://www.phnom-penh.diplo.de/contentblob/4526870/Daten/5446554/RED _Programme.pdf (accessed 11 October 2016).

Hakim, J. The Evolution of Towns and Cities in the Greater Mekong Subregion. In ADB. 2016. Urban Development in the Greater Mekong Subregion. Manila.

Jenkins, C., J. Leape, and L. Thomas. 2000. Gains from Trade in Southern Africa. Macmillan Press: London.

Maffioli, A., C. Pietrobelli, and R. Stucchi, eds. 2016. The impact evaluation of cluster development programs: methods and practices. IDB: Washington.

Matuto Corridor Logistics Initiative. http://www.mcli.co.za/mcli-web/mdc/sdi.htm; http://www.mcli.co.za/mcli-web/mdc/mdc.html (accessed 12 October 2016).

Mpumalanga Provincial Government. www.opportunityonline.co.za/articles/mega-opportunities-inmpumalanga-1281.html; www.mpumalanga.gov.za/otp/newsroom/speeches/archived _speeches/1999_archived_speeches/Speech10Aug99.htm (accessed 3 October 2016).

Mulenga, G. 2001. Developing Economic Corridors in Africa: Rationale for the Participation of the African Development Bank. NEPAD, Regional Integration and Trade Department - No. 1. April 2013.

Oxfam Australia. 2008. A Citizen's Guide to the Greater Mekong Region. Melbourne. 
Porter, M. 1998. Clusters and the New Competitive Agenda for Companies and Governments. In M. E. Porter. Boston, ed. On Competition. MA: Harvard Business School Press.

Rosenstein-Rodan, P. N. 1943. Problems of Industrialization of Eastern and South-Eastern Europe. The Economic Journal 53(210/211): 202-211.

Sequeira, S., O. Hartmann, and C. Kunaka. 2014. Reviving trade routes: evidence from the Maputo Corridor. Discussion papers, 14. SSATP. Washington.

Shutte, I. 2005. Maputo Development Corridor: Evaluation of First Phase CSIR. Pretoria.

Soderbaum, F. 2001. Institutional Aspects of the Maputo Development Corridor. Development Policy Research Unit, University of Cape Town. Cape Town.

Steinberg, F., and A. Plaza. The Greater Mekong Subregion Corridor Towns Development Projects. In ADB. 2016. Urban Development in the Greater Mekong Subregion. Manila.

Viljoen, P. 2006. Regional Integration through Infrastructure Development. www.un.org/esa/ffd/wpcontent/.../2006/11/20061122_NDBs-MSC-SA-Viljoen.ppt (accessed 2 October 2016).

Webster, D., and A. Gulbrandson. The Role of Cities and Connectivity in Promoting Regional Integration and Competitiveness. In ADB. 2016. Urban Development in the Greater Mekong Subregion. Manila. 


\section{Fostering Competitive Cities and Urban Areas in the Greater Mekong Subregion Building Inclusive Economic Clusters Sustainably}

This discussion paper focuses on the urban aspects of the Greater Mekong Subregion (GMS) corridor development and the institutional framework that will be needed to implement investments to bolster the region's competitiveness. Much work has been done on urban development in the GMS. The GMS Urban Strategy document clearly sets out three areas of focus and describes the cross-cutting theme of competitiveness. Given the experience on a range of projects in the intervening years, it is timely to consider potential strategies, and institutional and funding models, which could further enhance the competitiveness of the region. This paper seeks to canvass such strategies and models.

\section{About the Asian Development Bank}

ADB's vision is an Asia and Pacific region free of poverty. Its mission is to help its developing member countries reduce poverty and improve the quality of life of their people. Despite the region's many successes, it remains home to a large share of the world's poor. ADB is committed to reducing poverty through inclusive economic growth, environmentally sustainable growth, and regional integration.

Based in Manila, ADB is owned by 67 members, including 48 from the region. Its main instruments for helping its developing member countries are policy dialogue, loans, equity investments, guarantees, grants, and technical assistance. 